\title{
PRESENTASI DIRI NEWS ANCHOR PRIA CNN INDONESIA
}

\author{
Atika Ayu Lestari ${ }^{1}$, Indah Suryawati ${ }^{2}$ \\ Fakultas Ilmu Komunikasi, Universitas Budi Luhur, Jakarta
}

Naskah diterima tanggal 27 Agustus, direvisi tanggal 29 Agustus, disetujui tanggal 3 September

\begin{abstract}
Abstrak. Setiap manusia memiliki presentasi dirinya baik pada panggung depan dan panggung belakang. Presentasi diri ini dilakukan ketika seseorang berinteraksi dengan orang lain dan mengelola kesan melalui sebuah pertunjukan diri yang mengalami setting di hadapan khalayak. Penelitian ini bertujuan untuk mengungkap presentasi diri panggung depan dan panggung belakang news anchor pria CNN Indonesia. Teori yang digunakan adalah Teori Dramaturgi Erving Goffman. Penelitian ini menggunakan metode dramaturgi Erving Goffman. Data primer adalah yang didapatkan dari hasil wawancara mendalam yang dilakukan bersama dengan informan. Analisis data dilakukan secara deskriptif untuk mengkaji terkait news anchor bagaimana front stage dan back stage dirinya. Setelah menganalisa data tersebut, peneliti akan menghasilkan penelitian berbentuk kata-kata sebagai bukti tentang hasil yang diperoleh peneliti. Hasil penelitian menunjukkan bahwa kedua news anchor CNN Indonesia memiliki kesamaan pada panggung depan (front stage) yang meliputi setting, appearance, dan manner. Pada bagian panggung belakang (back stage) kedua news anchor CNN Indonesia memiliki aspek yang berbeda dikarenakan karakter yang dimiliki berbeda-beda. Pada penelitian ini, peneliti melihat Yudi Yudawan sebagai pribadi yang berwibawa dan 'kalem' diluar dirinya sebagai news anchor. Sedangkan pada Ryan Hasri, cenderung memiliki karakter yang menyenangkan dan cenderung apa adanya saat berinteraksi dengan individu lainnya.
\end{abstract}

\section{Kata kunci: Penyaji Berita, Presentasi Diri, Dramaturgi.}

Abstract. Every human being has their own presentations on both the front and back stage. Selfpresentation is done when a person interacts with others and manages the impression that it is expected to grow on others. This study aims to reveal the self-presentation front stage and backstage of male news anchor in CNN Indonesia. The theory used is by Erving Goffman Dramaturgy Theory, and compiles with dramaturgy method. While the primary data is obtained from the results of in-depth interviews. Data analysis is done descriptively to study related news anchor about the way of those male front stage and back stage itself. The results showes that the male news anchor in CNN Indonesia have similarities on the front stage (front stage) which includes setting, appearance, and manner. At the backstage stage, both news anchors of CNN Indonesia have different aspects because the characters are owned differently. In this study, the researcher sees Yudi Yudawan as a person of authority and 'calm' outside of himself as news anchor. While Ryan Hasri, tend to have a fun character and tend to be what it is when interacting with other individuals.

Keywords: News Anchor, Self Presentation, Dramaturgy. 


\section{PENDAHULUAN}

Peran news anchor terbilang sangat penting dalam suatu tayangan program berita di televisi. Dapat dikatakan, bagus tidaknya suatu tayangan program berita sangatlah ditentukan oleh bagus tidaknya performa news anchor yang membawakan program tersebut. Performa news anchor menjadi bagian penting dari wajah suatu tayangan program berita.

News anchor tak hanya dituntut untuk memiliki wawasan serta pengetahuan yang luas. Mereka pun dituntut untuk mampu bekerja dalam tekanan dan mempertahankan citra dirinya dihadapan khalayak luas. Bahkan presentasi diri news anchor dalam suatu tayangan program berita televisi harus memiliki image yang baik dan terkesan sebagai pribadi yang positif. Pandangan khayalak terhadap suatu program berita bergantung bukan hanya pada isi berita, tetapi juga terhadap pembawaan news anchor saat membacakan isi berita.

News anchor adalah seseorang yang membawakan materi berita atau penyajian berita dan sering terlibat memberikan improvisasi komentar dalam siaran langsung. Banyak anchor terlibat dalam penulisan berita bagi program yang dibawakan sendiri oleh anchor tersebut. Anchor biasanya juga terlibat dalam mewawancarai narasumber di studio atau memandu program diskusi. Tidak jarang menjadi komentator dalam berbagai program berita (Askurifai, 2009:156). Najwa Shihab (dalam Jaya, 2014:23) mengatakan, 'untuk menjadi news anchor ternyata enggak semudah membalikkan telapak tangan, lho! Butuh proses panjang. Ingat! News anchor bukan sekedar news reader selanjutnya kita sebut sebagai news presenter yang sekedar membacakan naskah berita yang ada di teleprompter. Seorang news presenter yang sudah bertahun-tahun kerja di stasiun televisi sekali pun tidak serta merta bisa disebut sebagai news anchor lalu belum turun ke lapangan, mengenal banyak narasumber, tahu cara memproduksi berita, dan mahir menulis naskah. Jadi, rasanya kalau mau jadi news anchor tuh memang harus jadi reporter dulu',

Masih menurut Najwa Shihab, "news anchor itu adalah “orang-orang pilihan”. Jadi, enggak bisa sembarang "ngaku-ngaku" news anchor, padahal kemampuannya baru sebatas news presenter. Soal kerja keras ini memang sepertinya wajib dipunyai oleh seorang calon news anchor, meningat ada gosip bahwa peluang jadi news anchor itu sangat sedikit. Dari puluhan reporter, cuma butuh beberapa news presenter, dan akhirnya cuma satu-dua yang jadi news anchor. Nah itu artinya peluang jadi news anchor memang benar sedikit "' (Jaya, 2014:81).

Peneliti memilih news anchor CNN Indonesia sebagai subjek dalam penelitian ini karena performa yang ditampilkan news anchor CNN Indonesia mampu membangun karaker yang baik berdasarkan profesi yang mereka jalani didepan khalayak (front stage). CNN Indonesia 
memiliki karakter news anchor yang berbeda-beda pada setiap programnya, ada yang tampil secara formal dalam membawakan acara seperti halnya pada program CNN Indonesia Breaking News dan pada CNN Indonesia News Room. Berbeda dengan program lainnya yaitu CNN Indonesia Good Morning yang dikemas dengan karakter pembawaan berita yang terkesan santai pada pagi hari. perbedaan karakter inilah yang menjadikan CNN Indonesia menjadi program yang berbeda dengan program berita lainnya selain dengan beragam program berita televisi lainnya. CNN pada dasarnya merupakan program berita yang sudah dikenal didunia dengan memiliki berbagai macam program acara yang ditayangkan di berbagai macam negara dan salah satunya adalah Indonesia.

CNN Indonesia hadir selama 24 jam untuk menyajikan berita-berita terupdate untuk memenuhi kebutuhan informasi bagi khalayak dari berbagai aspek. CNN Indonesia sendiri merupakan salah satu program berita yang memiliki sejumlah informasi yang menarik dan dikemas dengan program yang modern seiring dengan kemajuan teknologi saat ini. CNN Indonesia sendiri merupakan situs berita milik Trans Media yang bekerjasama dengan Turner International. CNN Indonesia dan CNN International adalah dua organisasi yang berbeda dan terpisah. Mereka independen dari satu sama lain, tetapi dapat bekerjasama dan saling membantu dalam peliputan berita besar.

Beragamnya program yang disuguhkan kepada khalayak, menjadikan CNN Indonesia berbeda dengan sejumlah program berita yang ada pada stasiun televisi lainnya. CNN Indonesia selain ditayangkan pada stasiun televisi TRANSTV dan TRANS7 juga hadir dalam televisi berbayar Transvision dan UseeTV serta dalam siaran live streaming pada web mereka yaitu CNNIndonesia.com, oleh sebab itu mereka hadir selama 24 jam bagi khalayaknya. Hal tersebut merupakan salah satu alasan mengapa peneliti mengambil news anchor pada CNN Indonesia dalam penelitian ini. Banyak sekali program yang ditayangkan dalam CNN Indonesia seperti CNN Indonesia Sports, CNN Indonesia Tech News, CNN Indonesia Showbiz News, CNN Indonesia Night News, CNN Indonesia Good Morning, CNN Indonesia Viral dan lain sebagainya.

Tentunya presentasi diri news anchor CNN Indonesia di hadapan orang lain, tidak selalu berjalan mulus seperti apa yang diinginkan, melainkan selalu saja akan ada gangguan. Untuk itulah pendekatan dramaturgi juga berkaitan dengan bagaimana cara mengatasi gangguangangguan tersebut. Meskipun begitu, kesalahan-kesalahan dalam menampilkan citra diri mereka dapat di antisipasi dengan baik.

Dalam perspektif dramaturgi, kehidupan ini dilihat berdasarkan sebuah pertunjukan teater yang dipertunjukan diatas sebuah panggung yang dimainkan oleh aktor dengan berbagai 
peran-peran dengan menggunakan bahasa verbal ataupun menggunakan atribut-atribut tertentu. Menurut Goffman, kehidupan sosial itu dapat dibagi menjadi panggung depan (front stage) dan panggung belakang (back stage). Wilayah depan merujuk kepada peristiwa sosial yang memungkinkan individu bergaya atau menampilkan pean formalnya. Mereka seperti sedang memainkan suatu peran di atas panggung sandiwara di hadapan khalayak penonton. Sebaliknya, wilayah belakang merujuk kepada tampat dan peristiwa yang memungkinkan mempersiapkan perannya di wilayah depan (Mulyana, 2013:114).

Goffman membagi panggung depan ini menjadi dua bagian: front pribadi (personal front) dan setting, yaitu situasi fisik yang harus ada ketika aktor harus melakukan pertunjukan. Tanpa setting, aktor biasanya tidak dapat melakukan pertunjukan. Misalnya seorang dosen memerlukan kelas sebagai setting tempat ia mempertunjukan perannya sebagai dosen. Front pribadi terdiri dari alat-alat yang dianggap khalayak sebagai perlengkapan yang dibawa ke dalam setting. Misalnya, seorang dosen di harapkan membawa buku-buku teks yang tebal ketika mengajar di kelas dan membawa peralatan pada saat mengajar seperti laptop dan proyektornya sebagai alat untuk presentasi. Personal front ini mencakup juga bahasa verbal dan bahasa tubuh sang aktor, misalnya berbicara sopan, pengucapan istilah asing, intonasi, postur tubuh, ekspresi wajah, pakaian, penampakan usia, ciri-ciri fisik, dan sebagainya (Mulyana, 2013:114$115)$.

Kontras dengan panggung depan, panggung belakang memungkinkan pembicara dengan menggunakan kata-kata kasar atau tidak senonoh, bersendawa, kentut, bersenandung, dan bersiul. Panggung belakang biasanya berbatasan dengan panggung depan dan bersembunyi dari pandangan khalayak. Hal ini dimaksudkan untuk melindungi rahasia pertunjukan. Oleh karena itu, khalayak biasanya tidak diizinkan memasuki panggung belakang, kecuali dalam keadaan darurat. Suatu pertunjukan akan sulit dilakukan apabila aktor membolehkan khalayak berada di panggung belakang (Mulyana, 2013:115). Menurut interaksionisme simbolik, manusia belajar memainkan berbagai peran dan mengasumsikan identitas yang relevan dengan peran-peran ini, terlibat dalam kegiatan menunjukan kepada satu sama lainnya siapa dan apa mereka. Dalam konteks demikian, mereka menandai satu sama lain dan situasi-situasi yang mereka masuki, dan perilaku-perilaku berlangsung dalam konteks identitas sosial, makna, dan definisi situasi (Mulyana, 2013:110)

\section{METODE PENELITIAN}

Paradigma konstruktivisme digunakan dalam penelitian ini untuk memaparkan presentasi diri news anchor pria CNN Indonesia, karena peneliti ingin mengamati dan mendapatkan data 
penelitian secara langsung dengan cara lebih mendalam untuk kemudian dianalisa dan diolah untuk dijadikan hasil penelitian, oleh karena itu paradigma konstruktivisme diharapkan akan menjadi cara pandang peneliti agar dapat melihat secara objektif terkait dengan presentasi diri news anchor pria CNN Indonesia. Penelitian ini menggunakan metode dramaturgi Erving Goffman. Data primer adalah yang didapatkan dari sumber pertama, atau tangan di lapangan. Sumber data ini responden atau subjek penelitian, dari hasil pengisian wawancara, observasi misalnya dari individu atau perorangan. Dapat peneliti jelaskan bahwa bentuk memperoleh sumber pertama dari seseorang atau individu di lapangan ini tentunya data didapatkan lewat wawancara (Kriyantono, 2008: 41).

Data primer yang digunakan peneliti adalah menggunakan data dari hasil wawancara. Peneliti menggunakan metode wawancara mendalam. Wawancara mendalam ini akan dilakukan bersama dengan informan. Data sekunder dalah data yang diperoleh dari sumber data kedua atau sumber sekunder. Data ini juga dapat diperoleh dari data primer penelitian terdahulu yang telah diolah lebih lanjut menjadi bentuk - bentuk seperti tabel, grafik, diagram, gambar, dan sebagainya (Moleong, :186). Di penelitian ini peneliti menggunakan data sekunder berupa datadata yang mendukung data primer, dan data ini di peroleh melalui dokumen-dokumen yang ada untuk mendukung data-data yang sudah ada agar penelitian ini mendapatkan hasil yang maksimal. Berdasarkan data primer dan sekunder yang di dapat, peneliti kemudian melakukan analisis data secara deskriptif untuk mengkaji terkait news anchor bagaimana front stage dan back stage dirinya. Setelah menganalisa data tersebut, peneliti akan menghasilkan penelitian berbentuk kata-kata sebagai bukti tentang hasil yang diperoleh peneliti.

\section{HASIL PENELITIAN DAN PEMBAHASAN}

News anchor pria CNN Indonesia layaknya seorang aktor sebuah pementasan, news anchor berakting mengelola sebuah penampilan (appearance) dan gaya bertingkah laku (manner). Sehingga menarik untuk memperoleh kesan yang mereka inginkan di hadapan khalayak luas atau penonton.

Subjek dalam penelitian ini adalah dua orang news anchor CNN Indonesia yaitu Yudi Yudhawan dan Ryan Hasri. Adapun kriteria yang dimiliki untuk dijadikan peneliti sebagai informan yaitu intensitas keduanya dalam melakukan siaran pada program CNN Indonesia dan perbedaan karakter kedua informan news anchor. Agar dapat melihat secara objektif terkait dengan presentasi diri news anchor pria CNN Indonesia, dipilih dua informan yang mengenal Yudi dan Ryan. Berikut informan dalam penelitian ini :

\section{Informan I}




$\begin{array}{cl}\text { Nama } & \text { : Yudi Yudhawan } \\ \text { Tempat, Tanggal Lahir } & \text { : Palembang, 13 Januari 1984 } \\ \text { Pekerjaan } & \text { : News Anchor CNN Indonesia } \\ \text { Informan II } & \text { : Ryan Hasri } \\ \text { Nama } & \text { : Aceh, 20 Juli 1991 } \\ \text { Tempat, Tanggal Lahir } & \text { : News Anchor CNN Indonesia } \\ \text { Pekerjaan } & \\ \text { Informan Pendukung } & \text { : Prasidya Puspa } \\ \text { a. Nama } & \text { : Partner kerja Yudi Yudawan dan Ryan Hasri } \\ \text { Keterangan } & \text { : Dinda Meidiansyah } \\ \text { b. Nama } & \text { : Program Director } \\ \text { Keterangan } & \end{array}$

Kedua news anchor memiliki kesamaan yang terdapat pada bagian panggung depan (front stage). Wilayah depan (front region), yaitu tempat atau suatu peristiwa sosial yang memungkinkan individu menampilkan peran formal atau bergaya layaknya aktor yang berperan. Wilayah ini disebut juga "panggung depan" (front stage) yang khalayak. Panggung depan memiliki kesempatan wilayah untuk menciptakan kesan tertentu (image) terhadap pertunjukannya yang skenarionya sudah diatur sedemikian rupa dan berbeda dengan yang ada pada wilayah belakang. Pada bagian depan panggung yang meliputi setting, appearance, dan manner.

\section{Setting}

Bagaimana kedua news anchor tersebut pada sebelum siaran telah memiliki persiapan dari berbagai aspek, seperti halnya tata panggung. Yudi Yudawan pada penampilan setting panggung terlihat memiliki kewibawaan yang sangat sudah diatur sebelumnya. Ia hanya mengikuti instruksi yang sebelumnya sudah di briefing terlebih dahulu sebelum siaran berlangsung, penataan diri yang terjadi kala itu adalah bagaimana ia akan menyampaikan berita dengan memilah bahan siaran pada saat itu dan mengedit kalimat-kalimat yang sudah di buat agar menurutnya sesuai dengan ucapannya pada saat menyampaikan berita.

"Kalau saat siaran memang kan sebelumnya sudah diatur dimana-dimananya gitu, tapi kadang kita ga pernah tau atau foner kaya tadi tiba-tiba ada kebakaran sama apa namanya live report dari lokasi-lokasi yang kadang-kadang kita gak tau peristiwanya karena tiba-tiba baru dateng kantor tiba-tiba ada kebakaran tadi di balik papan atau ada apa namanya kecelakaan tanah longsor gitu terus banyak research so far itu" Ryan Hasri membenarkan bahwa sebelum siaran berlangsung diadakan pengarahan terhadap anchor agar siaran berjalan lancar, mulai dari teks berita, pakaian, posisi duduk, ekspresi, intonasi menyampaikan berita, dan dari segi panggung yaitu mulai dari penataan cahaya, backsound, bumper in, bumper out, posisi kamera dan lain sebagainya.

\section{Appearance.}


Bagaimana penampilannya saat menjadi seorang anchor, pada umumnya semua news anchor yang berada pada CNN Indonesia memiliki penampilan yang serupa karena sebelumnya semuanya sudah dipersiapkan mulai dari pakaian dan make up yang ada. Penampilan yang dipresentasikan Yudi Yudawan sebagai seorang anchor saat bekerja memiliki panggung depan yang terkesan positif, seperti busana yang digunakannya cenderung formal (kemeja, jas, celana, sepatu), rapih, sopan, bersih, makeup yang cukup, serta memiliki tatanan rambut yang tertata rapih agar terlihat baik saat dipandang. Ryan Hasri menggunakan setelan pakaian yang tidak jauh berbeda dengan Yudi Yudawan, mulai dari setelan jas, celana bahan yang dikenakan, sepatu pantofel, dan juga dasi. Tampilan make up yang dikenakan oleh Ryan Hasri cukup simple seperti anchor pada umumnya yang hanya menggunakan bedak untuk membuat tampilannya merarik dan bagus ketika siaran berlangsung. Yang berbeda darinya yaitu penggunaan accsesoris yang digunakan oleh Ryan Hasri yaitu berupa jam tangan berwarna hitam, selain jam digunakan untuk menunjukan waktu, jam juga dapat digunakan sebagai bagian dari penampilan untuk meningkatkan rasa percaya diri penggunanya. Tatanan rambut Ryan Hasri terlihat rapi dari segi penampilannya, dengan disisir ke arah kanan dan ditambahkan pomade rambut.

"Untuk penampilan sendiri kalo sebelum siaran itu kan biasanya, pake bedak-bedak dikitlah make up seadanya buat pria.. ya itu penting, walaupun laki-laki tapi harus tetep sedikit-sedikit mah. Biar terlihat bagus looknya waktu siaran itu. Terus kalau baju yaa setelan jas gitu ajasih pokoknya intinya formal aja.."

\section{Manner}

Seorang news anchor dituntut memiliki gaya kepribadian yang berwibawa dan terlihat smart dalam berkomunikasi. Manner yang dilakukan Yudi Yudawan saat melakukan tugasnya menyampaikan berita adalah gerak tubuh seperti mengerakkan tangan dan pandangan mata yang ia dapatkan secara natural dan tanpa ia sadari, tatapan mata maupun gestur tubuh menentukan isi berita apakah hard news dan soft news yang tengah disampaikan saat ia menjadi news anchor. Mimik wajah yang tampak terlihat, ia sesekali melontarkan senyumannya ketika membacakan berita yang bersifat menghibur atau pada berita soft news dan terlihat serius ketika membawakan berita yang bersifat hard news.

Kesan formal namun terkesan santai yang disanpaikan pada saat Yudi Yudwan sebagai anchor membawakan program berita dapat memberikan impac bagi khalayak yang melihatnya. Impac tersebut berupa kesan bagi khalayak yang cenderung mempercayai berita tersebut secara akurat dan faktual karena karakter yang dibawakan oleh seorang anchor. Ryan Hasri membentuk karakternya sebagai news anchor berdasarkan dengan permainan ekspresi wajahnya membacakan berita. Kepahaman pada saat membacakan berita menjadi bentuk nilai plus bagi dirinya agar terlihat menarik di hadapan pemirsa dengan performa yang baik saat membacakan 
berita. Sementara itu, wilayah belakang (back region), yaitu tempat untuk mempersiapkan tempat perannya di wilayah depan. Wilayah ini disebut juga "panggung belakang” (back stage) atau kamar rias tempat pemain sandiwara bersantai mempersiapkan diri atau berlatih untuk memainkan perannya di panggung depan.

Pada wilayah panggung belakang memungkinkan pembicaraan dengan menggunakan katakata kasar atau senonoh, komentar-komnetar seksual terbuka, duduk dan berdiri sembrono, merokok, berpakaian seenaknya, menggunakan dialek atau bahasa daerah, mengomel, berteriak, bertindak agresif dan berolok-olok (Mulyana, 2013:115). Pada back stage inilah news anchor bersantai dan menjadi dirinya dengan apa adanya tanpa harus menyembunyikan presentasi dirinya atau pengelolaan kesannya kepada orang lain. Pada back stage ini pula anchor dapat melakukan hal-hal yang tidak dapat diperlihatkan pada fron $t$ stage dikarenakan back stage anchor tidak dapat terlihat khalayak luas dan hanya orang-orang terdekatnya saja. Tak ada seorangpun yang dapat mengetahui siapa diri kita sebenarnya selain diri kita sendiri tanpa terkecuali keluarga (orang tua, kakak, adik, suami, atau istri), teman, kekasih dll.

\section{Make Up}

Produk kosmetika berwarna yang artinya bila digunakan pada tubuh atau bagian tubuh tertentu akan menghasilkan warna. Beberapa contoh dari make-up adalah lipstick, mascara, eye liner, eye shadow, dan blush on. Namun dalam penampilan keseharian bagi seorang laki-laki make up merupakan hal yang sangat tidak diperlukan. Adapun make up hanya digunakan oleh laki-laki pada saat tertentu saja, seperti dalam sebuah pertunjukan drama atau dalam pertunjukan seperti halnya news anchor. Yudi Yudawan sebagai laki-laki pada umumnya hanya menggunakan make up hanya untuk menunjang penamplannya saat berada di depan kamera. Ketika berada diluar lingkungan anchor yudi terkesan santai dan 'cuek' dalam berbagai penampilannya pada kesehariannya. Begitu juga Ryan Hasri tidak mengenakan make up dalam menjalani aktifitasnya dalam keseharian diluar kegiatannya sebagai anchor.

\section{Pakaian}

Pesentasi diri seseorang juga dapat dilihat dari segi penampilan yaitu pakaian yang dikenakan tersebut. Bahkan untuk menilai karakter seseorang dapat ditentukan melalui pakaian yang ia kenakan. Keseharian pada Yudi Yudawan hanyalah sebagai businessman, yaitu dengan meneruskan usaha milik keluarganya. Namun kegiatan tersebut hanya dilakukan pada waktu luangnya saja telepas dari dunia anchor. Penampilan dalam kesehariannya, terkesan 'cuek' namun masih ada unsur fashionable karena seperti yang peneliti lihat ketka bertemu, Yudi Yudawan mengenakan pakaian sesantainya yaitu mengenakan polo shirt dan bawahan celana 
jeans dengan menggunakan sepatu kets. Tak hayal penampilannya ini cenderung rapih dan terkesan santai untuk dilihat. Keseharian Ryan Hasri mengenakan pakaian casual dengan mengenakan atasan berupa kemeja tanpa kerah dan pada bagian bawah celana chino (celana bahan twill) beserta ikat pinggang dengan dipadukan sepatu sneakers berwarna abu-abu. Tampilan tersebut ketika dapat dilihat menampilkan kesan yang santai dan jauh dari pada penampilan seorang anchor.

\section{Sikap dan Perilaku}

Sikap dan perilaku seseorang merupakan suatu tindakan yang dilakukan seseorang meliputi dirinya dan apa yang dilakukan dirinya untuk berinteraksi dengan orang lain maupun terhadap diri sendiri. Sikap dan perilaku pada seseorang berbeda-beda tergantung pada kepribadian dari orang itu sendiri. Yudi Yudawan saat ditemui oleh peneliti terlihat menunjukan sikap dan kepribadian yang humble dan baik. Hal ini banyak terlihat dari wawancara yang berlangsung antara Yudi Yudawan bersama peneliti. Sikap sopan dan berwibawa ditunjukannya saat melakukan wawancara. Selain memiliki sifat dan kepribadiannya tersebut Yudi Yudawan adalah seseorang yang mudah bergaul dan akrab terhadap orang disekelilingnya. Ryan Hasri merupakan seseorang pria yang humble, menarik, baik, dan lucu, hal ini dapat terlihat berdasarkan pada saat proses wawancara berlangsung dan dalam waktu kegiatannya diluar sebagai anchor. Banyak hal yang dilakukannya yang terkesan 'gokil' ketika menjadi seorang reporter edisi CNN Vlog yang dibawakan olehnya, dan hal tersebut tidak jauh berbeda dengan perilakunya dalam keseharian.

\section{Bahasa Tubuh}

Bahasa tubuh sendiri merupakan sebuah tanda yang ditimbulkan oleh gerak dan gestur tubuh, yang akan menimbulkan sebuah kesan dan persepsi bagi orang lain. Untuk bahasa tubuh ini hanya dapat dilihat oleh individu-individu yang menyadari hal bahasa tubuh lain lawan bicaranya. Yudi Yudawan menunjukan bahasa tubuh yang terlihat santai namun terkesan formal dengan Peneliti, hal tersebut terlihat ketika Yudi Yudawan menyampaikan deretan jawaban yang diberikan oleh Peneliti, Yudi Yudawan menjawab dengan kaki tertutup yang menunjukan bahwa Yudi Yudawan memiliki kepribadian yang pendiam, introvert, dan menghargai waktu. Hal tersebut terbukti dengan kedisiplinannya ketika peneliti membuat janji untuk bertemu untuk melakukan wawancara pada saat sebelumnya. Ryan Hasri dikenal dengan priadi yang humoris dan terkesan menyenangkan ketika berinteraksi dengan siapapun disekelilingnya. Ketika melakukan wawancara, tak hanya jawabannya yang terkesan sedikit melimpir dari pada topik pembahasan menjadi jawaban humor namun bahasa tubuh yang ditunjukan Ryan Hasri pun terkesan sangat santai dan ia berulang kali menggerakan tangannya. 


\section{Mimik Wajah}

Menimbulkan suatu emosional yang meliputi ekspresi gembira, sedih, marah, kecewa dan sebagainya. Mimik wajah yang ditunjukan oleh Yudi Yudawan cenderung ekspresif dan menunjukan mimik wajah yang bersemangat dengan tertawa. Mimik pada wajah menggambarkan orang tersebut dapat memberikan sebuah kesan emosional dari individu satu ke individu lainnya. Ryan Hasri pada saat berbicara menunjukan wajah tertawa menandakan suatu hal yang dibicarakannya menyenangkan untuk diceritakan kepada peneliti contoh seperti bercerita mengenai pengalaman bekerjanya untuk menjadi seorang anchor yang terselip kejadian-kejadian lucu didalam ceritanya.

\section{Isi Pesan}

Yudi Yudawan menunjukan bahwa isi pesan yang disampaikan olehnya tidak berdasarkan apa yang sebelumnya terjadi pada saat menjadi anchor karena menurutnya hal tersebut semua berdasarkan dengan apa yang menjadi bahasan dan dengan siapa ia berbicara saat itu. Ryan Hasri mengutarakan jawabannya dengan bijak dan cenderung informatif, dikarenakan karakternya yang menyenangkan apa yang Ryan Hasri sampaikan kepada peneliti maka peneliti dapat dengan mudah memahami apa yang ia sampaikan.

Tabel 1

Dramaturgi News Anchor Yudi Yudawan dan News Anchor Ryan Hasri

\begin{tabular}{|c|c|c|}
\hline Unsur & Yudi Yudawan & Ryan Hasri \\
\hline $\begin{array}{l}\text { Proses Presentasi Diri Anchor di } \\
\text { Lingkungan Kerja (Front Stage) }\end{array}$ & $\begin{array}{l}\text { Presentasi diri yang di } \\
\text { tampilkan Yudi Yudawan pada } \\
\text { bagian depan panggung } \\
\text { memiliki kesan yang terlihat } \\
\text { berwibawa dan penuh } \\
\text { karismatik keika menyampaikan } \\
\text { berita pada program CNN } \\
\text { Indonesia. Bahasa yang } \\
\text { digunakan ketika berbicara } \\
\text { sebagai seorang news anchor } \\
\text { menggunakan bahasa yang baik } \\
\text { dan benar sesuai dengan kamus } \\
\text { bahasa Indonesia dan terkesan } \\
\text { baku. Pakaian yang digunakan } \\
\text { ketika menjadi news anchor } \\
\text { merupakan pakaian yang rapih, } \\
\text { bersih serta berpenampilan } \\
\text { menarik untuk dilihat oleh } \\
\text { pemirsa. }\end{array}$ & $\begin{array}{l}\text { Presentasi diri yang ditampilkan } \\
\text { dapat terjadi dikarenakan penampilan } \\
\text { yang dibuat oleh Ryan Hasri dalam } \\
\text { pekerjaannya sebagai news anchor } \\
\text { televisi. Pakaian yang rapih dan } \\
\text { bersih dengan menggunakan setelan } \\
\text { jas, kemeja, dasi, celana bahan, dan } \\
\text { sepatu yang dikenakan disertakan } \\
\text { dengan tampilan waajah yang dipoles } \\
\text { makeup sewajarnya dapat } \\
\text { menampilkan panggung depan yang } \\
\text { memiliki banyak kesan baik dimata } \\
\text { pemirsa dirumah yang menyaksikan } \\
\text { tayangan. Tidak hanya } \\
\text { menyampaikan informasi, tetapi juga } \\
\text { lebih menjadi teman bagi pemirsa } \\
\text { yang ingin mengetahui informasi apa } \\
\text { saya yang terjadi didalam maupun } \\
\text { luar negeri sekalipun. }\end{array}$ \\
\hline Setting (Panggung) & $\begin{array}{l}\text { Setting yang ditampilkan sesuai } \\
\text { dengan tema dan apa yang akan } \\
\text { dibahas pada saat siaran akan } \\
\text { berlangsung, tema yang } \\
\text { ditentukan berpengaruh } \\
\text { terhadap penampilan dan } \\
\text { pembawaan yang akan } \\
\text { disampaikan oleh news anchor. }\end{array}$ & $\begin{array}{l}\text { Hal yang sama dilakukan oleh } \\
\text { informan, dimana apa yang akan } \\
\text { ditampilkan sebelumnya termasuk } \\
\text { kepada apa yang sebelumnya diatur } \\
\text { dan di beritahukan sebelumnya } \\
\text { kepada news anchor. Mulai dari segi } \\
\text { panggung, tata rias, background } \\
\text { panggung dan backsound yang akan }\end{array}$ \\
\hline
\end{tabular}




\begin{tabular}{|c|c|c|}
\hline & & disajikan. \\
\hline Appearance (Penampilan) & $\begin{array}{l}\text { News anchor Yudi Yudawan } \\
\text { dalam segi penampilan memiliki } \\
\text { karakter yang formal dan } \\
\text { berwibawa. Hal tersebut dapat } \\
\text { dilihat dari penampilannya } \\
\text { dalam berbusana sebagai news } \\
\text { anchor dengan menggunakan } \\
\text { setelan jas, celana bahan, dasi, } \\
\text { dan sepatu pantofel. Untuk } \\
\text { tatanan rambut Yudi Yudawan } \\
\text { terlihat rapih dengan rambut } \\
\text { yang disisir ke bagian belakang } \\
\text { dan terkesan formal. }\end{array}$ & $\begin{array}{l}\text { Ryan Hasri menggunakan setelan } \\
\text { pakaian yang tidak jauh berbeda } \\
\text { dengan Yudi Yudawan, mulai dari } \\
\text { setelan jas, celana bahan yang } \\
\text { dikenakan, sepatu pantofel, dan juga } \\
\text { dasi. Tampilan make up yang } \\
\text { dikenakan oleh Ryan Hasri cukup } \\
\text { simple seperti news anchor pada } \\
\text { umumnya yang hanya menggunakan } \\
\text { bedak untuk membuat tampilannya } \\
\text { merarik dan bagus ketika siaran } \\
\text { berlangsung. Yang berbeda darinya } \\
\text { yaitu penggunaan accsesoris yang } \\
\text { digunakan oleh Ryan Hasri yaitu } \\
\text { berupa jam tangan berwarna hitam, } \\
\text { selain jam digunakan untuk } \\
\text { menunjukan waktu, jam juga dapat } \\
\text { digunakan sebagai bagian dari } \\
\text { penampilan untuk meningkatkan rasa } \\
\text { percaya diri penggunanya. Tatanan } \\
\text { rambut Ryan Hasri terlihat rapi dari } \\
\text { segi penampilannya, dengan disisir } \\
\text { ke arah kanan dan ditambahkan } \\
\text { pomade rambut. }\end{array}$ \\
\hline
\end{tabular}

\begin{tabular}{|c|c|c|}
\hline Manner (Gaya) & $\begin{array}{l}\text { Gerakan yang ditampilkan dan } \\
\text { ekspresi wajah yang } \\
\text { diperlihatkan pada saat proses } \\
\text { siaran berlangsung menunjuka n } \\
\text { gerakan yang tidak terlalu } \\
\text { berlebihan, cara jalan yang } \\
\text { sewajarnya dan posisi badan } \\
\text { yang tetap tegap. }\end{array}$ & $\begin{array}{l}\text { Gaya (manner) yang disesuaikan } \\
\text { dengan berita yang akan disampaikan } \\
\text { pada saat siaran berlangsung dan } \\
\text { gesture tubuh yang tidak terlalu } \\
\text { banyak gerak saat membawakan } \\
\text { berita. }\end{array}$ \\
\hline $\begin{array}{l}\text { Proses Presentasi Diri Anchor di } \\
\text { Luar Lingkungan Kerja (Back } \\
\text { Stage) }\end{array}$ & $\begin{array}{l}\text { Ketika berada diluar terlepas } \\
\text { dirinya yang menjadi seorang } \\
\text { anchor presentasi dirinya akan } \\
\text { terlihat berbeda, namun ketika } \\
\text { perbedaan tersebut hanya } \\
\text { terlihat dari sisi teman } \\
\text { terdekatnya saja dan dengan } \\
\text { orang yang berinteraksi dengan } \\
\text { informan yang dikenal baik } \\
\text { menurutnya. Informan saat } \\
\text { berada diluar menjaga imagenya } \\
\text { dengan bersikap friendly dan } \\
\text { bersikap ramah kepada siapapun } \\
\text { yang mengenali dan } \\
\text { menyapanya. }\end{array}$ & $\begin{array}{l}\text { Presentasi diri yang ditampilkan pada } \\
\text { saat menjadi seorang anchor } \\
\text { sangatlah berbeda dengan diluar } \\
\text { kegiatannya sebagai anchor. Ketika } \\
\text { berada di tempat umum, informan } \\
\text { akan lebih bersikap bebas dan } \\
\text { menjadi dirinya sendiri baik dalam } \\
\text { berkomunikasi maupun dari segi } \\
\text { penampilannya. }\end{array}$ \\
\hline Make Up (Tata Rias) & $\begin{array}{l}\text { Tidak adanya penggunaan make } \\
\text { up bagi informan sebagai } \\
\text { seorang laki-laki. Penampilan } \\
\text { wajahnya terkesan cuek dan apa } \\
\text { adanya jauh dari penggunaan } \\
\text { make up pada saat siaran } \\
\text { sebagai seorang anchor yang } \\
\text { selalu menggunakan bedak atau } \\
\text { sedikit make up untuk } \\
\text { memberikan kesan yang baik } \\
\text { kepada khalayak. }\end{array}$ & $\begin{array}{l}\text { Seperti pada umumnya pria, informan } \\
\text { tidak mengenakan make up dalam } \\
\text { menjalani aktifitasnya dalam } \\
\text { keseharian diluar kegiatannya sebagai } \\
\text { anchor, informan hanya menunjang } \\
\text { penampilannya saat berada di depan } \\
\text { kamera saja dengan bantuan make up } \\
\text { sewajarnya. }\end{array}$ \\
\hline Pakaian & Diluar kegiatannya sebagai & Diluar kegiatannya sebagi anchor, \\
\hline
\end{tabular}


anchor, informan berpakaian santai dengan menggunakan kaos ( $t$-shirt) dengan bawahan celana jeans yang

digunakannya. Tak lupa ia mengenakan sepatu jenis sport penampilan yang terkesan santai dan simple.

Sikap dan Perilaku untuk memperlihatkan
Informan membedakan terhadap orang lain di lihat dari siapa ia berinteraksi, dimana ia melakukan interaksi tersebut, dan topik apa yang menjadi bahan pembicaraan. Informan terkesan memiliki sikap dan perilaku yang humble dan baik. Hal ini banyak terlihat dari wawancara yang berlangsung dan saat bertemu dengan kerabat informan. Berbeda hal nya pada saat informan tampil sebagai seorang anchor. informan mengenakan pakaian casual dengan mengenakan atasan berupa kemeja tanpa kerah dan pada bagian bawah celana chino (celana bahan twill) beserta ikat pinggang dengan dipadukan sepatu sneakers. Tak dapat dapat dipungkiri juga informan menggunakan pakaian keseharian seperti $t$-shirt jika tidak berpergian kemanapun.

Informan merupakan seseorang pria yang humble, menarik, baik, dan lucu, hal ini dapat terlihat berdasarkan pada saat proses wawancara berlangsung dan dalam waktu kegiatannya diluar sebagai anchor. Banyak hal yang dilakukannya yang terkesan 'gokil' ketika menjadi seorang reporter edisi CNN Vlog yang dibawakan olehnya, dan hal tersebut tidak jauh berbeda dengan perilakunya dalam keseharian. Perbedaan tersebut dapat terlihat sangat jelas ketika berinteraksi dengan informan diluar dari pekerjaannya dan dalam konteks lingkungan teman.

Bahasa Tubuh $\quad$ Bahasa tubuh yang diperlihatkan pada saat diluar menjadi anchor menunjukan kesan yang formal namun terihat santai, peneliti dapat melihat bahasa tubuh yang ditampilkan memiliki kesan bagi pemiliknya yaitu pribadi yang berwibawa, baik, dan tipe individu yang terkesan simple dan elegan dalam konteks berinterasksi dengan individu lainnya.

Pada informan terdapat bahasa tubuh yang terkesan santai dan mudah berinteraksi dengan akrab terhadap orang yang baru dikenalnya. Peneliti melihat gerakan menyilangkan kaki, dan tangan yang digerakan ketika informan berbicara dengan peneliti terkesan memiliki keakraban didalamnya. Berbeda halnya dengan bahasa tubuh yang ditampilkan pada saat siaran berlangsung, informan cenderung kaku dan tidak luwes dalan menggerakan tubuhnya untuk berinteraksi seperti biasanya dikarenakan terpaku pada teks dan hanya memainkan mimik wajah dan intonasi yang disampaikan.

Informan pada saat berbicara menunjukan wajah tertawa menandakan suatu hal yang dibicarakannya menyenangkan untuk diceritakan kepada peneliti. Hal tersebut menunjukan bahwa memang pada dasarnya semua bergantung pada pembahasan yang ada. menunjukan mimik wajah yang bahagia. Seperti saat percakapan pada saat sebelum memulai wawancara. Peneliti menjelaskan bahwa mimik wajah seseorang termasuk informan dapat berubah-ubah sesuai dengan dalam konteks apa ia berbicara. 


\begin{tabular}{|c|c|c|}
\hline & $\begin{array}{l}\text { pesan yang disampaikan } \\
\text { olehnya tidak berdasarkan apa } \\
\text { yang sebelumnya terjadi pada } \\
\text { saat menjadi anchor karena } \\
\text { menurutnya hal tersebut semua } \\
\text { berdasarkan dengan apa yang } \\
\text { menjadi bahasan dan dengan } \\
\text { siapa ia berbicara saat itu. } \\
\text { Peneliti dapat menyimpulkan } \\
\text { bahwa ketika informan } \\
\text { berinteraksi dengan individu } \\
\text { maupun pada saat ia menjadi } \\
\text { anchor itu semua bergantung } \\
\text { dengan apa yang ingin } \\
\text { dibicarakan dan } \\
\text { menyesuaikannya agar tidak } \\
\text { terjadinya miscomunication }\end{array}$ & $\begin{array}{l}\text { kita berkomunikasi dengan siapa, } \\
\text { dimana dan dengan topik apa itu akan } \\
\text { mempengaruhi isi pesan yang } \\
\text { disampaikan. Namun pada saat ia } \\
\text { menjadi anchor sebelumnya apa yang } \\
\text { akan disampaikan sudah ditentukan } \\
\text { sebelumnya, ia harus mempelajari } \\
\text { apa yang akan disampaikannya } \\
\text { kepada khalayak. }\end{array}$ \\
\hline Cara Bertutur atau Gaya Bahasa & $\begin{array}{l}\text { Cara bertutur meliputi bagian } \\
\text { dari kepribadian informan } \\
\text { terlepas dari peran anchor yang } \\
\text { dimilikinya. Peneliti melihat } \\
\text { kesan yang disampaikan saat } \\
\text { berinteraksi kepada peneliti } \\
\text { memiliki tutur kata dan gaya } \\
\text { bahasa yang sopan dan santun } \\
\text { terlepas dari pekerjaannya } \\
\text { sebagai anchor televisi }\end{array}$ & $\begin{array}{l}\text { Informan memiliki cara } \\
\text { berkomunikasi yang menyenangkan } \\
\text { di luar kegiatannya sebagai anchor } \\
\text { televisi. Hal ini dapat peneliti } \\
\text { sampaikan karena gaya berbicara } \\
\text { maupun gaya bahasa yang } \\
\text { disampaikan memiliki kesan } \\
\text { keakraban seperti interaksi antara } \\
\text { individu dengan sesama temannya. } \\
\text { Namun hal tersebut dapat berbeda } \\
\text { ketika informan menjadi seorang } \\
\text { anchor televisi yang memiliki cara } \\
\text { bertutur dan gaya bahasa yang } \\
\text { terkesan sangat formal karena profesi } \\
\text { tersebut banyak di tonton khalayak } \\
\text { luas yang dapat dijadikan contoh oleh } \\
\text { khalayak. }\end{array}$ \\
\hline
\end{tabular}

Sumber : Hasil Penelitian, 2018

\section{SIMPULAN}

Bentuk dari perilaku komunikasi pada upacara pernikahan Betawi diantaranya adalah pengarakan menggunakan rebana ketimpring serta membaca shalawat sebelum masuk ke tempat kediaman mempelai wanita, pembacaan saritilawah yang wajib dilaksanakan pada setiap pernikahan Betawi, adanya atraksi bukaan palang pintu sebelum mempelai pria memasuki kawasan resepsi. Namun, ada beberapa hal budaya yang memang tidak bisa dipenuhi seperti petasan sebagai ikon dari sebuah pernikahan Betawi namun pada saat pernikahan Mas Deni dan Mbak Nia berlangsung mereka tidak menggunakan petasan di karenakan tempat yang mereka jadikan resepsi tidak mengizinkan membunyikan petasan dan mereka tidak menggunakan tarian topeng yang menjadi ciri khas dari Betawi karena mereka merasa dengan adanya palang pintu 
sudah cukup memberikan simbol bahwa mereka adalah orang Betawi, jadi anggaran untuk hiburan tarian memang tidak ada. Dari tujuh proses pernikahan pada tradisi Betawi yang di antaranya ngedelengin, ngelamar, bawa tande putus, akad nikah, kebesaran, negor dan pulang tige ari, yang paling umum digunakan di zaman sekarang hanya ngelamar, bawa tande putus dan kebesaran, sisanya sudah sangat jarang dan tidak diaplikasikan lagi oleh banyak orang hal ini dikarenakan perkembangan zaman yang semakin modern membuat orang yang membuat acara pernikahan hanya melihat acara inti seperti lamaran, bawe tande putus (tunangan), dan besaran (resepsi).

Makna komunikas verbal dan nonverbal pada upacara pernikahan Betawi adalah bahasa yang kental Betawi masih sangat terdengar jelas di antara mayoritas undangan dan keluarga pengantin serta para pelakon dalam upacara tersebut yang menggunakan bahasa Betawi seperti duduk nike, maen, penganten, gue, iye, di mari, dll. Makna komunikasi nonverbal dapat dilihat dari baju seragam yang digunakan, gerakkan, nada suara, serta kontak mata.

Unsur asimilasi dalam upacara pernikahan Betawi terlihat dari tusukkan konde yang digunakan oleh sang pengantin wanita merupakan asimilasi dari budaya Cina, yaitu terdapat tusukkan konde berbentuk burung Hong serta terdapat unsur asimilasi dari budaya Arab, yaitu tusukkan konde yang di beri nama tusukkan lam (bahasa Arab) dan cadar. Alat musik serta makanan pun memiliki unsur asimilasi dari negara lain di antaranya Cina, Portugis, India, Belanda, dan Arab.

\section{DAFTAR PUSTAKA}

\section{Buku:}

Kuswarno, Engkus. (2009). Fenomenologi: Metodologi Penelitian Komunikasi. Bandung: Widya Padjadjaran

Knapp, Mark L dan Judith A. Hall. (2006). Nonverbal Communication in Human Interaction, Sixth Edition. USA : Thomson Wadsworth.

Daymon, Christine., dan Immy Holloway. (2008). Metode-metode Riset Kualitatif: dalam Public Relations dan Marketing Communications. Yogyakarta: Penerbit Bentang.

Mulyana, D. (2004). Ilmu Komunikasi, Suatu Pengantar. Bandung: PT. Remaja Rosdakarya

Mindess, Sidney et al. (2003)., “CONCRETE 2ND EDITION”. Pearson Education, Inc. USA

Rahkmat, Jalaluddin. 2008, Psikologi Komunikasi. Bandung: PT. Remaja Rosdakarya

Wood Julia. (2013), Komunikasi Interpersonal: Interaksi Keseharian. Jakarta: Salemba Humanika

\section{Jurnal}

Putra, A (2015), Studi Fenomenologi Ta'aruf Sebagai Cara Menentukan Pasangan Hidup Pada Partai Keadilan Sejahtera. Jurnal Ilmiah LISKI (Lingkar Studi Komunikasi), [Online] 209223. Available from: http://journals.telkomuniversity.ac.id/liski/article/ view/823/613. 


\section{Artikel Internet:}

Liputan6.com (2018) https://www.liputan6.com/regional/read/3620412/berapa-jumlah-baha-sadaerah-di-indonesia-saat-ini.

\section{Skripsi, Tesis, Disertasi:}

Dewi, I Gusti Ayu. 2015. Aktivitas Komunikasi Upacara Pernikahan Suku Sasak (Studi Etnografi Komunikasi Dalam Upacara Kawin Culik Di Desa Rembitan, Lombok Tengah) Skripsi. Universitas Telkom, Bandung, Indonesia. 